\title{
Social Entrepreneurship as a Tool of Sustainable Development
}

DOI: 10.12776/QIP.V24I3.1463

Jozef Bl’anda, Nataša Urbančíková

Received: 2020-05-18 Accepted: 2020-05-18 Published: 2020-11-30

\begin{abstract}
Purpose: The article deals with the analysis of the perception of social entrepreneurship in Slovakia by social entrepreneurs. The main aim is to identify how social entrepreneurs perceive individual aspects of social entrepreneurship in Slovakia, including the role of social entrepreneurship in sustainable development.

Methodology/Approach: The analysis was based on data obtained from a questionnaire survey conducted among social entrepreneurs in Slovakia. The survey was attended by representatives of 35 social enterprises from Slovakia. A seven-point rating of Likert scale used within the questionnaire. The mode, median and interquartile range of answers were used to evaluate the questionnaire.
\end{abstract}

Findings: Social entrepreneurs pointed out that social entrepreneurship is still in development in Slovakia and several obstacles causing this situation. They also agreed that the most important benefit of social entrepreneurship in Slovakia is the effort to solve social problems. The research results show that the priority of social entrepreneurs in Slovakia is not to support sustainable development.

Research Limitation/implication: The research was limited by the number of social entrepreneurs who participated in the survey. More than half of social enterprises, registered in Slovakia were not willing to participate in the survey.

Originality/Value of paper: The article brings important findings in the field of social entrepreneurship, which are based on the practical experience of social entrepreneurs in Slovakia.

Category: Research paper

Keywords: social entrepreneurship; social entrepreneurs; sustainable development 


\section{INTRODUCTION}

Nowadays, many countries, not only in Europe but also in the world, are constantly striving for progress and development. These countries focus mainly on supporting economic growth, sustainable development and improving the quality of life. Therefore, they need to find tools that can support the development of these areas. One of the most important tools for supporting sustainable development is social entrepreneurship. One of the most important tools in this field is social entrepreneurship, which is an important tool for sustainable development (Seelos and Mair, 2005a). Social entrepreneurship brings many benefits and solves many social, economic and environmental problems. The social economy and social enterprises employ more than 11 million people in the European Union, which is around $6 \%$ of total EU employment (European Commission, 2020b; Barna, 2012). Because of these positive benefits, it is necessary to analyze social entrepreneurship and provide support for social enterprises.

According to the European Commission's Social Business Report in Slovakia, low awareness and understanding of the concept of social entrepreneurship can be a major barrier to the development of social entrepreneurship in Slovakia (European Commission, 2014). This is the main reason why the focus should be given on the analysis of perception and awareness of social entrepreneurship is Slovakia. One of the most important stakeholders who play an important role in the development of social entrepreneurship is social entrepreneurs. The analysis of the perception of social entrepreneurship by social entrepreneurs can provide important information about social entrepreneurship in the county. Based on this information, it will be possible to evaluate the overall level of social entrepreneurship and to develop strategies designed to support the development of social entrepreneurship in Slovakia.

\section{THEORETICAL BACKGROUND}

To have a good understanding of the role of social entrepreneurship in sustainable development, it is necessary to define social entrepreneurship and its role in sustainable development. This section describes social entrepreneurship and its goals, social entrepreneurs and the role of social entrepreneurship in sustainable development.

\subsection{Social Entrepreneurship}

Social entrepreneurship is the process of creating value by finding new combinations of resources. These combinations are primarily aimed at creating social value by stimulating social change or meeting social needs (Lepoutre et al., 2013). Social entrepreneurship can take many forms and can exist in the form of small local businesses as well as large multinationals. The social benefits of 
antisocial entrepreneurship can be targeted at small local communities or communities around the world (Brooks, 2009).

The social mission of social entrepreneurship is related to the fact that social enterprises must have a clearly defined social goal that they want to achieve (Certo and Miller, 2008). Social entrepreneurs and social enterprises develop products and services that directly meet basic human needs that other social institutions and enterprises are unable or unwilling to provide (Seelos and Mair, 2005a). The main difference between commercial entrepreneurship and social entrepreneurship is that social entrepreneurship focuses the creation of social value as its priority, while others focus more on making a profit (Mair and Martí, 2006). Commercial companies try to create added high value for their customers, but the task of social entrepreneurship is to create social value for their clients (Dees, 2007).

Ssocial entrepreneurship can be characterized as a process that helps accelerate social change and addresses the social needs in a way that is not focused in direct financial benefits for entrepreneurs (Mair and Martí, 2006). Zahra et al. (2009) associate social entrepreneurship with activities and processes that focus on defining, discovering and exploiting opportunities to strengthen social welfare by creating new enterprises or innovative managing existing enterprises. Innovation and innovative solutions are very important features of social entrepreneurship. In advanced economies, social entrepreneurs have become important actors, who are significantly involved in implementing changes to society by seeking innovative and cost-effective methods to solve social issues such as poverty or gender inequality (Zahra et al., 2008).

For other authors, such as Paredo and McLean (2006) and Emerson (2003), the most important for social entrepreneurship is recognizing, exploiting and creating opportunities. They also consider social entrepreneurship as an activity where individuals or groups of people focus on creating social value while being able to recognize and exploit business opportunities. The main feature of social entrepreneurship is the use of business innovations and the risk-taking ability associated with such entrepreneurship. Social entrepreneurs usually deal with areas where they see a lack of social needs or create new social opportunities that the public or private sector has failed to solve adequately.

According to Nicholls (2008), social entrepreneurship focuses mainly on the following priorities:

- the provision of goods and services that the market and the public sector do not want or are unable to provide;

- skills development;

- job creation;

- supporting the process of integration of socially excluded people back into society. 
Santos (2012) points out on the possible significant impact of social entrepreneurship on the country's economic system because it can contribute to the development of new industries, introduce new business models, and try to redirect resources to solve social issues that are neglected by the state and society.

\subsection{The Role of Social Entrepreneurship in Sustainable Development}

Sustainable development is generally defined as development that aims to meet the needs of the current generation without compromising the needs of future generations. The concept of sustainable development was initially associated only with the protection and preservation of the environment. Nowadays, its interdisciplinary nature comes to the fore, which includes social, economic and environmental areas that are mutually reinforcing (European Commission, 2020a). In general, three basic aspects of sustainable development have been identified. It includes economic, social and environmental development (Bawa and Seidler, 2009). Sustainable development focuses on several objectives across different areas of development.

The main goal of sustainable development is to achieve long-term stability of the economy and the environment. It is necessary to ensure that economic, environmental and social factors are taken into account to achieve this goal. Sustainable development also aims to create and maintain prosperous and resilient social, economic and environmental systems (Pisano, 2012).

Several authors and studies emphasize the role of social entrepreneurship in sustainable development. Social entrepreneurship is considered an important tool for supporting sustainable development, as it contributes to the achievement of the internationally recognized goals of sustainable development (Seelos and Mair, 2005a). The role of social entrepreneurship in sustainable development is mostly based on the great potential of business ideas and activities in the social field (Jouen, 2012). In addition to social benefits, social enterprises also pursue environmental and economic sustainability (Barrutia and Echebarria, 2012).

Social entrepreneurship incorporates innovative approaches to addressing the environment issues and human rights and is widely regarded as an important element of countries' sustainable development (Mair and Noboa, 2003). Besides, social entrepreneurship addresses issues that are identified in the context of sustainable development as one of the most important. This includes poverty alleviation, the fight against climate change, inclusive growth, access to education for all and tackling social problems and so on. Social entrepreneurship is also concerned with providing products and services for organizations, individuals, society as a whole and future generations. It is well known that sustainable development cannot be achieved if the basic needs of poor and disadvantaged groups remain unsatisfied. Here, social entrepreneurship plays an important role, as it focuses primarily on alleviating the most serious problems of these groups of the population (Seelos and Mair, 2005b). 


\section{METHODOLOGY}

The aim of the article is to analyze the perception of individual aspects of social entrepreneurship in Slovakia by social entrepreneurs. These aspects include the general perception of social entrepreneurship, benefits of social entrepreneurship, obstacles that hinder the development of social entrepreneurship and measures that can support the development of social entrepreneurship in Slovakia. The aim of the article is also to identify appropriate measures to support the development of social entrepreneurship in Slovakia.

The analysis of the perception of social entrepreneurship by social entrepreneurs was based on data obtained from a questionnaire survey conducted among social entrepreneurs in Slovakia. The questionnaire was based ed on questions used in the studies Mataboge (2014) and Swee-Sum (2016).

The questionnaire consisted of 14 questions, which were focused on various aspects of social entrepreneurship in Slovakia. The first group of questions concerned the general perception of social entrepreneurship by social entrepreneurs. Social entrepreneurs evaluated aspects of social entrepreneurship related to the tasks, priorities and goals of social entrepreneurs, the position and perception of social entrepreneurship by society. The second group of questions focused on the benefits that social entrepreneurship can bring to the individuals and society as a whole. The third group of questions concerned the evaluation of identified possible obstacles that hinder the development of social entrepreneurship and the establishment of social enterprises in Slovakia. Another group of questions concerned measures that would support the development of social entrepreneurship in Slovakia. Respondents were also asked what their motivation was to engage in social entrepreneurship and what real problems they faced. The questionnaire survey was conducted during February and March 2020 in the form of an electronic questionnaire and a telephone interview. Representatives of all social enterprises that were officially registered in the register of social enterprises of the Ministry of Labor, Social Affairs and Family of the Slovak Republic until $10^{\text {th }}$ February 2020 were asked to participate in the survey. A total of 85 social enterprises were contacted. Out of the total number of 85 contact social entrepreneurs, we received answers from 35 of them.

The analysis used a 7-point Likert scale, on which respondents evaluated aspects of social entrepreneurship, where 1 means strong disagreement and 7 means strong agreement. Mode, median, IQR, and average of responses were used to evaluate responses. The mode indicates which response occurred the most frequently. The median gives the mean value of the answers and divides all the answers in half, sorted from the lowest value to the highest. IQR (inter-quartile range) represents the difference between the $3^{\text {rd }}$ and $1^{\text {st }}$ quartile of response distribution and indicates the variability of responses. In this case, the IQR can take values from 0 to 6 . A lower IQR value means a higher degree of response variability and, conversely, a higher value means a lower rate of response 
variability. A higher mode and median value indicates a higher rate of agreement and vice versa.

The questionnaire also contained open-ended questions. The questionnaire also contained open-ended questions concerning the practical experience of social entrepreneurs in the field of social entrepreneurship.

Based on the most important findings from the previous analysis, the measures for support development of social entrepreneurship were identified. These measures have been supplemented by opinions provided by selected experts for social entrepreneurship in Slovakia. Opinions of these experts were obtained by personal interviews. The experience of social entrepreneurship and qualifications were taken into account in the selection of experts who took part in the expert interviews. At the same time, the selection was based on the inclusion of experts from various fields of social entrepreneurship from the public, private and nonprofit sectors and with different views on this field.

\section{RESULTS AND FINDINGS}

Based on the results, it can be summarized the perception of social entrepreneurs on selected aspects of social entrepreneurship in Slovakia. It covers preception of general characteristics of social entrepreneurship, benefits, barriers of development and measures to support social entrepreneurship.

\subsection{Motivation to Establish a Social Enterprise}

Social entrepreneurs can be motivated to start a social business by various factors. Germak and Robinson (2013) point out the basic factors that influence social entrepreneurs, such as internal motivation, helping society and nonfinancial goals.

The most frequently mentioned reason for setting up a social enterprise was to help disadvantaged people and solve social problems in their region. This is in line with the findings of Ghalwash, Tolba and Ismail (2017). They found out that social entrepreneurs are motivated mainly by social problems and challenges. The second most common reason is related to the benefits of the transition of a sheltered workshop to a social enterprise. Most social enterprises in Slovakia were created by the transformation from a sheltered workshop. The reason is the possibility of obtaining better government support, subsidies and possible help to a larger number of people in the case of a social enterprise compared to a sheltered workshop. According to the respondents, the advantage of social enterprises over sheltered workshops is that they do not have to keep separate accounts and employees are no longer tied to the workplace, they can also work from home and in another position. According to social entrepreneurs, the Ministry of Labor, Social Affairs and Family of the Slovak Republic itself also issued suggestions for sheltered workshops to transform themselves into social enterprises. Entrepreneurs also mentioned that they had a disadvantaged person 
or a person with special needs as a significant factor that motivated them. A total of $63 \%$ of all social entrepreneurs participating in the survey said they had such a person in their family. The presence of a disadvantaged person in the family has a significant effect on the motivation of individuals to engage in social entrepreneurship.

Previous entrepreneurial experience has also played an important role in motivating to start a social business. As many as $81.5 \%$ of all social entrepreneurs who participated in the survey already had experience with entrepreneurship. Ghalwash, Tolba and Ismail (2017) also point to the importance of previous experiences. Mahmud et al. (2011) state that the presence of an entrepreneur in the family is also an important element. In this case, the presence of the entrepreneur in the family was not so important, as the ratio between the social entrepreneurs who had an entrepreneur in the family and those who did not was balanced. In the total number of respondents, $51.9 \%$ of social entrepreneurs had an entrepreneur in the family, and $48.1 \%$ did not.

\subsection{The General Perception of Social Entrepreneurship}

All respondents agreed that social entrepreneurship is a good idea with great potential, but in Slovakia, it is still in development. They observe shortcomings in this field, mainly related to low awareness and institutional arrangements.

Only $37 \%$ of social entrepreneurs consider social entrepreneurship in Slovakia to be well developed, and $63 \%$ think that there is not enough awareness of this entrepreneurship in Slovakia. According to social entrepreneurs, the most important characteristic of social entrepreneurship in Slovakia is new jobs creation. With this statement, the highest agreement of the answers of social entrepreneurs in Slovakia was observed. This is indicated by the IQR value, which is at the level of 0.5 , and it means a minimum degree of variability of respondents' answers. Both mode and median of responses were 6 , which means a high level of overall agreement of the respondents.

Social entrepreneurs also agreed with the statements such as the priority of social entrepreneurship is to reinvest profits to achieve social goals, social enterprises are good employers, social entrepreneurship is intended for people who want to change the unfavourable social situation.

Social entrepreneurs have agreed that social enterprises can compete with commercial enterprises. The level of agreement was not as significant here as in previous statements, but even so, a low level of variability of respondents' responses is observed. This is indicated by the IQR value, which is at the level of 1.5 and value of mode which is 6 . This is an interesting finding, as the extent to which social enterprises can compete with commercial enterprises is debatable, as social enterprises are limited by focusing on their social goals. In addition, most of these enterprises employ disadvantaged people and people with special needs, who require a special approach and do not achieve high labour productivity compared to regular employees. On the other hand, the social 
entrepreneurship experts who participated in the expert interviews disagreed with this statement. For example, Eva Havelková, a national analysis of the European Commission for gender and social issues and an expert in the field of social entrepreneurship, stated in an expert interview that social enterprises cannot compete with commercial enterprises. She argued that social enterprises achieve low productivity and flexibility compared to commercial enterprises. Marek Rakoš, the founder and director of one of the most successful social enterprises in Slovakia, is also of the opinion that social enterprises are not able to compete with commercial enterprises. He points out that social enterprises should focus primarily on areas and sectors that are not attracted to commercial enterprises due to low financial returns. However, abroad we can also find the opposite views of social entrepreneurship experts. Thust (2012), Deloitte's Director of Corporate Social Responsibility, points out that social enterprises have the potential to be competitive with mainstream businesses, but only with sufficient government support. Therefore, more attention should be given to the issue of the competitiveness of social enterprises.

\subsection{Perception of the Benefits of Social Entrepreneurship}

The value of the median and mode of response for all identified benefits of social entrepreneurship was 6 , which means the overall consent of the respondents. The IQR value for all benefits was 1, which indicates a low degree of variability of responses. Table 1 shows the mode, median, IQR and mean of responses related to the perception of the benefits of social entrepreneurship in Slovakia.

Table 1 - Perception of the Benefits of Social Entrepreneurship

\begin{tabular}{|l|c|c|c|c|}
\hline Benefit & Mode & Median & IQR & Mean \\
\hline Integration of disadvantaged citizens into society & 6 & 6 & 1 & 5.85 \\
\hline Addressing social inequality & 6 & 6 & 1 & 5.48 \\
\hline Increasing employment & 6 & 6 & 1 & 5.44 \\
\hline Sustainable development & 6 & 6 & 1 & 5.30 \\
\hline Development of social services & 6 & 6 & 1 & 5.22 \\
\hline
\end{tabular}

The most important benefit of social entrepreneurship in Slovakia, identified by social entrepreneurs is the integration of disadvantaged people into society. This is also based on their motivation to establish a social enterprise. Most social entrepreneurs were motivated to establish a social enterprise because of the opportunity to help disadvantaged groups. The second most important benefit was the effort to address social inequality in the region. This benefit was important especially for the representatives of social enterprises founded by municipalities. The most vulnerable groups identified by social entrepreneurs were unskilled people, under-educated people, Roma people, and older people. 
Social entrepreneurs agreed that the benefit of social entrepreneurship in Slovakia is also the support of sustainable development. However, this benefit was not as important as the previously mentioned benefits. Social entrepreneurs have placed support for sustainable development in the penultimate place. Based on these results, we can assume that social entrepreneurship in Slovakia is not considered an important tool to support sustainable development. However, social entrepreneurship is generally considered to be an important tool that can support sustainable development. Many authors and studies such as Seelos and Mair (2005b), Jouen (2012), Barrutia and Echebarria (2012), Mair and Noboa (2003), and Azmat (2013) point to the importance of social entrepreneurship in support sustainable development.

Based on this, it is necessary to focus on raising awareness of this role of social entrepreneurship among social entrepreneurs in Slovakia. This approach would help develop the potential of social entrepreneurship in the implementation of activities and strategies for sustainable development in Slovakia.

In addition to the benefits in Table 1, social entrepreneurship experts pointed to other important benefits of social entrepreneurship. They pointed out that the advantage of social entrepreneurship is also a better possibility of cooperation of several social enterprises, which can help each other. In commercially oriented companies, this form of cooperation is limited, as these companies usually only cooperate in cases where such cooperation is mutually beneficial.

\subsection{Perception of Obstacles to the Development of Social Entrepreneurship}

Social entrepreneurs have had to deal with many obstacles during the establishment and operation of social enterprises, and they have practical experience in this field. Table 2 shows the mode, median, IQR value and mean of responses of social entrepreneurs to individual obstacles to the development of social entrepreneurship in Slovakia. Table 2 shows the mode, median, IQR and mean of responses related to the perception of obstacles to the development of social entrepreneurship in Slovakia.

The most serious obstacle was the administrative complexity associated with social entrepreneurship. The value of the mode and median of the answers is 5 , which indicates a high overall level of agreement of the respondents. The IQR value of this barrier is 3 , which indicates a high degree of variability of responses. The reason is that several respondents do perceive the administrative burden as an obstacle but consider it to be also necessary to ensure transparency in this area. On the other hand, most social entrepreneurs perceive administration and bureaucracy to be a significant obstacle in setting up and managing a social enterprise. 
Table 2 - Perception of Obstacles to the Development of Social Entrepreneurship

\begin{tabular}{|l|c|c|c|c|}
\hline Benefit & Mode & Median & IQR & Mean \\
\hline Administrative complexity & 6 & 5 & 3.0 & 4.78 \\
\hline Unclear legislation & 5 & 5 & 2.0 & 4.74 \\
\hline Lack of information on social entrepreneurship & 6 & 5 & 3.0 & 4.58 \\
\hline Too much risk social entrepreneurs face & 6 & 5 & 3.0 & 4.33 \\
\hline Social entrepreneurship is time-consuming & 6 & 5 & 4.0 & 4.22 \\
\hline Fear of debt & 5 & 5 & 2.0 & 4.19 \\
\hline High tax burden & 4 & 4 & 3.5 & 4.11 \\
\hline $\begin{array}{l}\text { Lack of personal preconditions of social } \\
\text { entrepreneurs }\end{array}$ & 5 & 4 & 2.0 & 4.04 \\
\hline Insufficient support from the government & 3 & 3 & 2.5 & 3.70 \\
\hline $\begin{array}{l}\text { Negative attitude to social entrepreneurship by } \\
\text { society }\end{array}$ & 2 & 4 & 3.0 & 3.62 \\
\hline Corruption in obtaining government support & 2 & 2 & 2.5 & 2.67 \\
\hline
\end{tabular}

Social entrepreneurs emphasized, for example, that the establishment of new social enterprises was planned rather than the transformation of sheltered workshops into social enterprises. All documents necessary for the registration and operation of a social enterprise have been prepared only for newly established enterprises and are not compatible with sheltered workshops, and it complicates their filling. Another problem is waiting times related to administrative. In some cases, the whole process of registration and other administrative duties takes up to 9 months. Entrepreneurs have to wait for confirmations and changes in the commercial register for up to 30 days.

The second most serious obstacle is the unclear legislation on social entrepreneurship. A high level of respondents' agreement was observed here. Entrepreneurs are often forced to seek legal advice on the interpretation of the law during the establishment of a social enterprise. Even lawyers sometimes have problems interpreting the law. Uncertainties in the legislation are reflected not only in the understanding of the law by entrepreneurs but mainly in the different interpretation of the legislation by various public institutions such as regional centres of social economy, labour offices and the Ministry of Labor, Social Affairs and Family of the Slovak Republic. It is not clear what the different types of contributions can be used for. For example, social entrepreneurs often find that the Public Procurement Office does not respect the possibility for public entities to reserve public contracts exclusively for registered social enterprises.

According to social entrepreneurs, another significant obstacle to the development of social entrepreneurship in Slovakia is the lack of public information and awareness about social entrepreneurship. This also corresponds 
with the conclusions of the European Commission (2014) and social entrepreneurship experts, who also perceive low public awareness as one of the most serious obstacles.

The least serious obstacle to the development of social entrepreneurship in Slovakia is corruption in obtaining support. Social entrepreneurs pointed out that the whole system of support for social enterprises is more transparent as it was in the past. The administration associated with social entrepreneurship largely eliminates the possibility of corruption.

\subsection{Perception of Measures to Support the Development of Social Entrepreneurship}

In this part of the research, social entrepreneurs evaluated measures that could help in the development of social entrepreneurship in Slovakia. Table 3 shows the mode, median, IQR and mean of responses related to the perception of measures to support the development of social entrepreneurship in Slovakia.

Table 3 - Perception of Measures to Support the Development of Social Entrepreneurship

\begin{tabular}{|l|c|c|c|c|}
\hline Benefit & Mode & Median & IQR & Mean \\
\hline Financial support for social enterprises & 6 & 6 & 0.75 & 5.85 \\
\hline $\begin{array}{l}\text { Better access to public procurement for social } \\
\text { enterprises }\end{array}$ & 6 & 6 & 1.00 & 5.78 \\
\hline $\begin{array}{l}\text { Raise public awareness of social } \\
\text { entrepreneurship }\end{array}$ & 6 & 6 & 0.50 & 5.65 \\
\hline Promotion of best practice examples & 6 & 6 & 1.00 & 5.48 \\
\hline $\begin{array}{l}\text { Support for municipalities in establishing social } \\
\text { enterprises }\end{array}$ & 6 & 6 & 1.00 & 5.37 \\
\hline $\begin{array}{l}\text { Government award for social entrepreneurs } \\
\begin{array}{l}\text { Incorporate information about social } \\
\text { entrepreneurship into school curricula }\end{array}\end{array}$ & 5 & 5 & 2.00 & 4.56 \\
\hline
\end{tabular}

Respondents included financial support and better access to public procurement for social enterprises as the most important measure that would help support the development of social entrepreneurship in Slovakia. Both the mode and the median of the responses in these measures indicate a strong agreement of the respondents. The IQR values indicate a low variability of the responses. According to social entrepreneurs, financial support should also take into account the overall resulting positive social impact of the social enterprise and not only the percentage of reinvested earnings. 
Other measures proposed by social entrepreneurs related to financial support:

- Shortening the waiting period for reimbursement of wages costs;

- Increase in financial contributions in the initial phase of establishing a social enterprise;

- Tighter financial controls in companies and increased transparency (there are the cases that social enterprises receive contributions for more disadvantaged employees than they employ);

- The better setting of service vouchers, or their cancellation and provision of a direct subsidy for an invoice.

Although social entrepreneurs perceive financial support as the most important measure that will support the development of social entrepreneurship in Slovakia, significant financial support can be counterproductive. Social entrepreneurship experts who took part in expert interviews also pointed out that financial support from the government may not be an effective tool to support social entrepreneurship and social enterprises should strive for financial selfsufficiency. There are very successful entrepreneurship systems in developed countries where direct financial government support for social enterprises is limited.

Social entrepreneurs propose to increase the awareness of mayors of municipalities and other public entities about the possibilities of assigning public procurement contracts for social enterprises, as many of them are not aware of this possibility. An increase in the mandatory share of public procurements for social enterprises to cities, municipalities and self-governing regions would also help in the development of social entrepreneurship.

Incorporation of information on social entrepreneurship into school curricula is not perceived as an important tool to support the development of social entrepreneurship. It was ranked the last measure. On the other hand, the selected experts on social entrepreneurship emphasized the focus on incorporating the subjects of information about social entrepreneurship into the curricula of primary and secondary schools. Europpean Commission (2014) perceive the low awareness about social entrepreneurship as one of the biggest obstacles of development of social entrepreneurship in Slovakia. Education in this area of primary and secondary school pupils can be an important tool to improve this situation.

In addition to the measures listed in Table 3, social entrepreneurs also listed other practical measures that would help the development of social entrepreneurship in Slovakia. Inclusion of social enterprises and their activities in regional action plans would be an important tool. There have been attempts and efforts by social enterprises to do so, but they have been rejected by the relevant authorities. Simplifying the process of admitting disadvantaged people could help as well. 
There is a problem that people with special needs often do not go to the employment office and therefore it is not possible to employ them.

\section{CONCLUSION}

This article was focused on the analysis of the perception of social entrepreneurship by social entrepreneurs in Slovakia. Based on the analysis, it may be concluded that social entrepreneurs in Slovakia perceive social entrepreneurship as a tool for solving social problems, but it is still in development in Slovakia. Only $37 \%$ of social entrepreneurs perceive social entrepreneurship in Slovakia to be well developed. One of the most important findings is related to the role of social entrepreneurship in sustainable development. Many authors and studies emphasize its importance in the application of sustainable development. However, social entrepreneurship in Slovakia is not perceived as a tool od sustainable development. Therefore, appropriate measures should be adopted to raise the awareness of social entrepreneurs about the potential of social entrepreneurship in this field.

\section{REFERENCES}

Azmat, F., 2013. Sustainable Development in Developing Countries: The Role of Social Entrepreneurs. International Journal of Public Administration [e-journal], 36(5), pp.293-304. doi: 10.1080/01900692.2012.756891.

Barna, C., 2012. Social economy: going local to achieve the Strategy Europe 2020. Romania Case. Review of Applied Socio-Economic Research, 3(1), pp.1421.

Barrutia, J. and Echebarria, C., 2012. Greening regions: the effect of social entrepreneurship, co-decision and co-creation on the embrace of good sustainable development practices. Journal of Environmental Planning and Management [ejournal], 55(10), pp.1348-1368. doi: 10.1080/09640568.2012.657298.

Bawa, K.S. and Seidler, R., 2009. Dimensions of Sustainable Development. In: K.S. Bawa and R. Seidler, eds. 2009. Dimensions of Sustainable Development. EOLSS Publications. vol. I., chaper 1.

Brooks, A.C., 2009. Social Entrepreneurship: A Modern Approach to Social Value. Pearson Prentice Hall.

Certo, S. and Miller, T., 2008. Social entrepreneurship: Key issues and concepts. Business Horizons [e-journal], 51(4), pp.267-271. doi: 10.1016/j.bushor.2008.02.009.

Dees, J., 2007. Taking social entrepreneurship seriously. Society [e-journal], 44(3), pp.24-31. doi: 10.1007/BF02819936. 
Emerson, J., 2003. The Blended Value Proposition: Integrating Social and Financial Returns. California Management Review [e-journal], 45(4), pp.35-51. doi: $10.2307 / 41166187$.

European Commission, 2014. A map of social enterprises and their eco-systems in Europe. Country Report: Slovakia. [pdf] European Union. Availbable at: <https://ec.europa.eu/social/BlobServlet?docId=12999\&langId=en> [Accessed 28 October 2020].

European Commission, 2020a. Social Economy In The EU - Mercado Interior, Industria, Emprendimiento Y Pymes - European Commission. [online] Available at: <http://ec.europa.eu/growth/sectors/social-economy_es> [Accessed 16 May 2020].

European Commission, 2020b. Prístup EÚ k trvalo udržatel’nému rozvoju 2020. [online] Available at: <https://ec.europa.eu/info/strategy/internationalstrategies/sustainable-development-goals/eu-approach-sustainabledevelopment_sk> [Accessed 10 March 2020].

Germak, A. and Robinson, J., 2013. Exploring the Motivation of Nascent Social Entrepreneurs. Journal of Social Entrepreneurship [e-journal], 5(1), pp.5-21. doi: 10.1080/19420676.2013.820781.

Ghalwash, S., Tolba, A. and Ismail, A., 2017. What motivates social entrepreneurs to start social ventures? Social Enterprise Journal [e-journal], 13(3), pp.268-298. doi: 10.1108/SEJ-05-2016-0014.

Jouen, M., 2012. The Cohesion Pact: Weathering the Crisis. [pdf] Notre Europe Jacques Delors Institute. Available at: <https://institutdelors.eu/wpcontent/uploads/2018/01/cohesionpolicy_m.jouen_notreeurope_april2012.pdf> [Accessed 28 October 2020].

Lepoutre, J., Justo, R., Terjesen, S. and Bosma, N., 2013. Designing a global standardized methodology for measuring social entrepreneurship activity: the Global Entrepreneurship Monitor social entrepreneurship study. Small Business Economics [e-journal], 40(3), pp.693-714. doi: 10.1007/s11187-011-9398-4.

Mahmud, M.M.A., Mohamed, Z., Rezai, G. and Shamsudin, M.N., 2011. The Influence of Personality Traits and Demographic Factors on AgroEntrepreneurship Education among Graduates. In: IEDRC (International Economics Development and Research Center), International Conference on Innovation, Management and Service. Singapore, Singapore, 16-18 September. Singapore: IACSIT Press. pp.343-347.

Mair, J. and Martí, I., 2006. Social entrepreneurship research: A source of explanation, prediction,f and delight. Journal of World Business [e-journal], 41(1), pp.36-44. doi: 10.1016/j.jwb.2005.09.002. 
Mair, J. and Noboa, E., 2003. Social Entrepreneurship: How Intentions to Create a Social Enterprise Get Formed. IESE Working Paper No. D/521. Available at SSRN: <https://ssrn.com/abstract=462283> [Accessed 28 October 2020].

Mataboge, D.M., 2014. Social entrepreneurship among Diepsloot youth. Master thesis. University of the Witwatersrand. Available at: <http://wiredspace.wits.ac.za/bitstream/handle/10539/14899/DINAH\%20MATA BOGE\%20\%20RESEARCH\%20REPORT\%20FINAL\%20revised\%209\%20Jun e\%202014.pdf?sequence $=2>$ [Accessed 28 October 2020].

Nicholls, A., 2008. Social entrepreneurship: New models of sustainable social change. OUP Oxford.

Peredo, A. and McLean, M., 2006. Social entrepreneurship: A critical review of the concept. Journal of World Business [e-journal], 41(1), pp.56-65. doi: 10.1016/j.jwb.2005.10.007.

Pisano, U. 2012. Resilience and Sustainable Development: Theory of resilience, systems thinking. European Sustainable Development Network (ESDN), 26, 50p.

Santos, F., 2012. A Positive Theory of Social Entrepreneurship. Journal of Business Ethics, 111(3), pp.335-351.

Seelos, C. and Mair, J., 2005a. Social entrepreneurship: Creating new business models to serve the poor. Business Horizons [e-journal], 48(3), pp.241-246. doi: 10.1016/j.bushor.2004.11.006.

Seelos, C. and Mair, J., 2005b. Social Entrepreneurship - The Contribution of Individual Entrepreneurs to Sustainable Development. IESE Business School Working Paper No. 553. Available at SSRN: <https://ssrn.com/abstract=701181> [Accessed 28 October 2020].

Swee-Sum, L. and Weina, Z., 2016. Public Perception Study on Social Enterprises in Singapore. [pdf] Singapore: Asia Centre for Social Entrepreneurship \& Philanthropy, NUS Business School. Available at: <https://www.raise.sg/images/resources/pdf-files/SE-Public-Perception-StudyFull-Report.pdf> [Accessed 28 October 2020].

Thust, B., 2012. Social Enterprise Can Compete With The Mainstream - But It Needs Tailored Support. The Guardian, [online]. 2 July 2012. Available at: $<$ https://www.theguardian.com/social-enterprise-network/2012/jul/02/socialenterprise-compete-mainstream> [Accessed 17 May 2020].

Zahra, S.A., Gedajlovic, E., Neubaum, D.O. and Shulman, J., 2009. A typology of social entrepreneurs: Motives, search processes and ethical challenges. Journal of Business Venturing [e-journal], 24(5), pp.519-532. doi: 10.1016/j.jbusvent.2008.04.007.

Zahra, S.A., Rawhouser, H.N., Bhawe, N., Neubaum, D.O. and Hayton, J.C., 2008. Globalization of social entrepreneurship opportunities. Strategic Entrepreneurship Journal [e-journal], 2(2), pp.117-131. doi: 10.1002/sej.43. 


\section{ABOUT AUTHORS}

Jozef Bl'anda - (J.B.) Technical University of Košice, Košice, Slovak Republic, Department of Regional Sciences and Management, PhD. Student, e-mail: jozef.blanda@tuke.sk, Author's ORCID: 0000-0003-1063-7315.

Nataša Urbančíková - (N.U.) Technical University of Košice, Košice, Slovak Republic, Department of Regional Sciences and Management, Assoc. Prof., e-mail: natasa.urbancikova@tuke.sk, Author's ORCID: 0000-0002-2158-5517.

\section{AUTHOR CONTRIBUTIONS}

J.B. - formal analysis, investigation, resources, data curation, draft preparation; N.U. - validation, review and editing, supervision; J.B, N.U. - methodology.

\section{CONFLICTS OF INTEREST}

The authors declare no conflict of interest. The funders had no role in the design of the study; in the collection, analyses, or interpretation of data; in the writing of the manuscript, or in the decision to publish the results.

\section{CONFLICTS OF INTEREST}

The authors declare no conflict of interest. The funders had no role in the design of the study; in the collection, analyses, or interpretation of data; in the writing of the manuscript, or in the decision to publish the results.

(C) 2020 by the authors. Submitted for possible open access publication under the terms and conditions of the Creative Commons Attribution (CC-BY) license (http://creativecommons.org/licenses/by/4.0/). 